\title{
PENINGKATAN PENGETAHUAN IBU HAMIL MELALUI DISKUSI KELOMPOK TENTANG PERSEPSI DAN TRADISI KELIRU PADA MASA HAMIL DI DESA CIKUNIR KECAMATAN SINGAPARNA TAHUN 2018
}

\author{
OLEH :
}

\author{
CHANTY YUNIE, S.ST,M.Kes
}

(chanty.yunie@gmail.com)

\section{ANNISA RAHMIDINI, S.ST., M.Keb.}

(annisarahmidini@gmail.com)

\section{A. DASAR PEMIKIRAN}

Kehamilan merupakan suatu keadaan dimana seorang wanita yang didalam rahimnya terdapat embrio atau fetus. Kehamilan dimulai pada saat masa konsepsi hingga lahirnya janin, dan lamanya kehamilan dimulai dari ovulasi hingga partus yang diperkirakan sekitar 40 minggu dan tidak melebihi 43 minggu (Kuswanti, 2014). Jumlah ibu hamil di Indonesia pada tahun 2017 tercatat sekitar 5.324.562 jiwa. Sedangkan di Jawa Tengah, jumlah ibu hamil mencapai 590.984 jiwa (Kemenkes RI, 2018).

Kondisi kesehatan calon ibu pada masa awal kehamilan akan mempengaruhi tingkat keberhasilan kehamilan serta kondisi status kesehatan calon bayi yang masih didalam rahim maupun yang sudah lahir, sehingga disarankan agar calon ibu dapat menjaga perilaku hidup sehat dan menghindari faktor-faktor yang dapat mempengaruhi kondisi calon ibu pada masa kehamilan (Johnson, 2016).

Sosial budaya dapat dilihat sebagai pola dalam suatu wilayah lokal, seringkali dipandang secara birokratis dan sesuatu yang terorganisir, berkembang, berbudaya termasuk teori pemikiran sistem kepercayaan dan aktivitas sehari-hari, hal ini dapat diterapkan dalam praktek keseharian. Terkadang sosial budaya digambarkan menjadi suatu yang tidak dapat ditangkap oleh akal sehat atau sesuatu diluar kemampuan panca indra (Cicourel, 2013).

Kebudayaan memiliki unsur yang sama dalam setiap kebudayaan di dunia. Baik kebudayaan kecil bersahaja dan terisolasi maupun yang besar, kompleks dan dengan jaringan hubungan yang luas. Kebudayaan sangat mudah berganti dan dipengaruhi oleh kebudayaan lain, sehingga akan menimbulkan berbagai masalah yang besar. Dalam suatu kebudayaan terdapat sifat sosialis masyarakat yang didalamnya terdapat suatu ikatan sosial tertentu yang akan menciptakan kehidupan bersama (Sulismadi \& Sofwani, 2011). Kebudayaan mencakup suatu pemahaman komprehensif yang sekaligus bisa diuraikan dan dilihat beragam vairabel dan cara memahaminya. Kebudayaan dalam arti suatu pandangan yang menyeluruh yang menyangkut pandangan hidup, sikap dan nilai. Pembangunan kebudayaan dikaitkan dengan upaya memperbaiki kemampuan untuk recovery, bangkit dari kondisi yang buruk, bangkit untuk memperbaiki kehidupan bersama, bangkit untuk menjalin kesejahteraan. Dalam hal inilah sosial budaya berperan untuk 3 memberikan solusi terbaik bagi beragam bidang kehidupan (Widianto \& Pirous, 2009).

Budaya pada masa kehamilan dan persalinan di sebagian daerah telah terjadi pergeseran namun di sebagian lain masih dipertahankan. Hal ini seperti yang dijelaskan oleh O'Neil (2006) bahwa semua budaya yang diwariskan cenderung untuk berubah tetapi ada kalanya juga dipertahankan. Ada proses dinamis yang mendukung diterimanya hal-hal dan ide-ide baru dan ada juga yang mendukung untuk mempertahankan 
kestabilan budaya yang ada. Hiller (2003) menyatakan bahwa ketika perubahan terjadi, maka terjadi destruksi nilainilai tradisional, kepercayaan, peran dan tanggungjawab, pendidikan, keluarga dan lain-lain yang hampir simultan dengan proses konstruksi cara baru sebagai pengaruh dari perubahan sosial. Nilai dan ritual yang baru ini menggantikan nilai dan ritual yang lama. Namun di sebagian masyarakat adakalanya terjadi kompromi yang mana nilai dan ritual baru dijalankan dengan tanpa menghilangkan nilai dan ritual lama.

Berdasarkan studi pendahuluan melalui wawancara singkat yang dilakukan di Di Wilayah Desa Cikunir Kabupaten Tasikmalaya terdapat ibu hamil yang memiliki kepercayaan-kepercayaan tentang acara makanan dan kebiasaan makan yang sudah turun-temurun dilakukan seperti contoh larangan untuk makan dipiring besar, makanan pedas, nanas, duren, tape dan yang lainya dengan alasan akan membahayakan kesehatan bayi. STIKes Respati sebagai satusatunya sekolah tinggi ilmu kesehatan di Kabupaten Tasikmalaya memiliki tanggung jawab untuk memberikan kontribusi terhadap permasalahan terkait dengan kesehatan di Kabupaten Tasikmalaya melalui kegiatan Tri Dharma Perguruan Tinggi salah satunya dengan kegiatan pengabdian kepada masyarakat. Salah satu upaya nyata STIKes Respati adalah dengan melaksanakan kegiatan pengabdian kepada masyarakat dengan judul : Peningkatan Pengetahuan Ibu Hamil Melalui Diskusi Kelompok Tentang Persepsi Dan Tradisi Keliru Pada Masa Hamil Di Desa Cikunir Kecamatan Singaparna Tahun 2018

\section{B. TUJUAN KEGIATAN}

Kegiatan ini bertujuan untuk meningkatkan Pengetahuan Ibu Hamil Melalui Diskusi Kelompok Tentang Persepsi Dan Tradisi Keliru Pada Masa Hamil Di Desa Cikunir Kecamatan Singaparna

\section{SASARAN}

Seluruh Ibu Hamil di Wilayah Puskesmas Desa Cikunir Kecamatan Singaparna berjumlah 41 ibu hamil.

\section{TEMPAT DAN WAKTU PELAKSANAAN}

Kegiatan dilaksanakan di Aula Desa Desa Cikunir Kecamatan Singaparna dan dilaksanakan pada Tanggal 17 September s.d 06 Oktober 2018.

\section{E. HASIL KEGIATAN}

Kegiatan abdimas ini mencakup kegiatan :

1. Kegiatan penggalian persepsi dan tradisi pada ibu hamil

2. Diskusi kelompok untuk meningkatkan pengetahuan ibu hamil

Hasil nya sebagai berikut :

a. Pantangan/Larangan Yang Harus Diikuti Ibu Pada Saat Hamil

\section{Jangan Makan dipiring besar}

Berdasarkan hasil didapatkan bahwa responden memiliki persepsi bahwa ibu hamil tidak boleh makan dipiring besar yaitu 27 orang (65.9\%).

Hal ini tidak sesuai dengan teori dimana kebutuhan gizi ibu hamil merupakan hal yang penting yang harus yang harus dipenuhi selama kehamilan berlangsung. Resiko akan kesehatan janin yang sedang dikandung dan ibu yang mengandung akan berkurang jika ibu hamil mendapatkan gizi dan nutrisi yang seimbang. Oleh karna itu keluarga dan ibu hamil haruslah memperhatikan mengenai hal ini. Gizi atau nutrisi ibu hamil kondisinya sama saja dengan pengaturan 
gizi mengenai pola makan yang sehat.Kebutuhan gizi ibu hamil meninkat $15 \%$ dibandingkan dengan kebutuhan wanita normal. Peningkatan gizi ini di butuhkan untuk pertumbuhan ibu dan janin. Makanan dikonsumsi ibu hamil $40 \%$ digunakan untuk pertumbuhan janin dan sisanya $60 \%$ digunakan untuk pertumbuhan ibunya. Secara normal kenaikan Berat Badn Ibu Hamil berkisar antara 12-14 kg.

\section{Jangan Makan Pisang dari Pohon yang Tumbang}

Berdasarkan hasil didapatkan bahwa responden memiliki persepsi bahwa Jangan Makan Pisang dari Pohon yang Tumbang yaitu 24 orang $(58.5 \%)$. Karna memakan pisang dari pohon yang tumbang dapat mengakibatkan rahimnya keluar ini merupakan keyakinan/tradisi ibu akibat budaya yang diyakininya.

Menurut Susiloningtyas (2007), Kebutuhan nutrisi salah satunya adalah zat besi selama hamil dengan rata-rata $800 \mathrm{mg}$ $-1040 \mathrm{mg}$. Kebutuhan ini diperlukan untuk $: \pm 300 \mathrm{mg}$ diperlukan untuk pertumbuhan janin, $\pm 50 \mathrm{mg}-75 \mathrm{mg}$ untuk pembentukan plasenta, $\pm 500 \mathrm{mg}$ digunakan untuk meningkatkan massa hemoglobin maternal atau sel darah merah, $\pm 200 \mathrm{mg}$ lebih akan dieksresikan lewat usus, urin, dan kulit, serta $\pm 200 \mathrm{mg}$ lenyap ketika melahirkan.

Pisang sejak lama telah dikenal sebagai buah lezat dan berkhasiat bagi kesehatan. Buah pisang mengandung kalium (potasium) yang bermanfaat untuk penyeimbangan $\mathrm{pH}$ atau derajat keasaman didalam lambung (Lalage, 2013). Selain itu, kalium. bermanfaat untuk pengendalian tekanan darah, memengaruhi irama jantung, terapi darah tinggi, membersihkan karbondioksida didalam darah, berperan dalam kepekatan saraf dan otot, serta memicu kerja otot dan simpul saraf (Astrawan, 2008). Kalium yang tinggi juga akan memperlancar pengiriman oksigen ke otak dan membantu keseimbangan cairan di dalam tubuh (Kowalski, 2010).

\section{Jangan Minum Air ES}

Berdasarkan hasil penelitian didapatkan bahwa responden memiliki persepsi bahwa ibu hamil yang mengkonsumsi Air es beresiko bahwa bayi yang dikandungnya anak lahir tidak normal (bayi besar) sebanyak 25 responden $(61.0 \%)$.

Hal ini tidak sesuai dengan teori yang menyebutkan bahwa ibu yang mengkonsumsi air es atau minuman dingin selama masa kehamilan seperti es krim, sirup dan minuman yang lainya mengandung es akan melahirkan bayi dengan ukuran yang lebih besar dibandingkan pada berat yang normal. Padahal air es dan bayi tidak ada hubunganya sama sekali. Bayi besar atau yang disebut dengan makrosomia ini adalah dimana kondisi bayi yang lahir dengan berat badan lebih dari $4 \mathrm{~kg}$. Hal ini umumnya di sebabkan oleh ibu hamil yang mengidap penyakit diabetes (kencing manis).

Ibu yang mengkonsumsi air es selama kehamilan tidak berpengaruh dengan bayi besar, yang dapat menyebabkan bayi besar apabila ibu hamil mengkonsumsi air es ditambah dengan pemanis (gula, sirup dan yang lainya).

Pemanis merupakan senyawa kimia yang sering digunakan untuk keperluan produk olahan pangan, industri serta minuman dan makanan kesehatan. Menurut Peraturan Menteri Kesehatan (Menkes) RI Nomor 235, pemanis termasuk ke dalam bahan tambahan kimia, selain zat yang lain seperti antioksidan, pemutih, pengawet, dan lain sebagainya. Pemanis berfungsi untuk meningkatkan cita rasa dan aroma, memperbaiki sifat-sifat fisik, sebagai pengawet, dan untuk memperbaiki sifat-sifat kimia sekaligus merupakan sumber kalori bagi tubuh.

\section{Tidak Boleh Makan Nanas, Duren dan Tape}

Berdasarkan hasil didapatkan bahwa responden memiliki persepsi bahwa ibu hamil tidak boleh makan Nanas, Duren dan tape 
sebanyak 21 responden $(51.2 \%)$.

Masyarakat di Desa Cikunir mempunyai pantangan tidak meboleh makan Nanas, Duren dan Tape karna makanan tersebut membuat ibu hamil terjadi keguguran, pantangan ini sudah dari turun temurun nenek moyangnya.

Buah yang hampir ditabukan oleh berbagai suku/daerah di Indonesia adalah buah nenas. Masyarakat percaya bahwa ibu hamil yang mengonsumsi buah nanas akan menyebabkan keguguran, "Landep", menyebabkan korengan, diare, proses persalinan akan sulit dan kulit bayi bersisik, gatal, kepala anak seperti nanas, menyebabkan panas pada janin, anak akan membesar sehingga sulit saat persalinan, dan membahayakan janin. Buah nanas mengandung enzim bromelin yang dapat menstimulasi pengeluaran prostaglandin. Kadar prostaglandin yang meningkat dapat menyebabkan stimulasi kontraksi uterus. Selain itu, buah nanas juga mengandung serotonin yang juga memiliki peran dalam merangsang kontraksi uterus.

Duren mengandung senyawa sulfur yang disebut dietil disulfida yang dapat menghambat kerja enzim aldehyde dehydrogenase (ALDH) dalam hati yang berfungsi untuk memecah alkohol. Ditambah lagi, durian sudah tinggi kalori, jadi menambahkan alkohol akan membuat hal sulit bagi perut dan hati untuk mencerna makanan. Hal ini dapat menyebabkan gejala hangover yang berlebihan. Kadar alkohol dalam darah yang gagal dipecah oleh tubuh, karena dihambat oleh durian akan berubah menjadi sangat beracun. Anda dapat menjadi sangat kebingungan, tidak responsif, mengalami pernapasan pendek, bahkan kehilangan kesadaran hingga koma. Selain itu, meski durian tidak mengandung kolesterol dan lemak jenuh, makan durian tetap bisa meningkatkan tekanan darah. Kadar alkohol yang terlalu tinggi dalam tubuh bisa makin menyebabkan tekanan darah Anda melonjak di luar batas. Hipertensi kemudian meningkatkan risiko Anda mengalami serangan jantung, stroke, atau gagal jantung kongestif.
Tingkat alkohol dalam darah yang melebihi batas wajar juga dapat melemahkan otot-otot jantung, yang juga akan mempengaruhi paru, hati, otak, dan sistem organ dalam tubuh lainnya. Kadar alkohol yang terlalu tinggi dalam darah dapat menyebabkan kerusakan otak permanen dan menyebabkan jantung berdetak tidak normal (aritmia jantung), yang telah dikaitkan dengan kematian mendadak.

Kandungan dalam tape terdapat kadar alkohol yang dikandungnya, dapat menyebabkan terjadinya faktor resiko mengalami penyakit hati. Hal ini dikarenakan alkohol dimetabolisme di dalam organ hati, sehingga membuat organ hati bekerja lebih berat. Penyakit hati paling sering terjadi akibat kebiasaan mengkonsumsi alkohol adalah sirosis hati. Walaupun ada yang mengatakan bahwa kandungan alkohol dari tape tidak begitu besar, namun tetap saja hal tersebut akan menjadi akumulasi pada saat sering dikonsumsi. Selain itu dalam beberapa pendapat mengatakan, bahwa ketika mengkonsumsi tape singkong selain dapat menyebabkan resiko penyakit hati pada Ibu hamil, diduga juga dapat merusak atau memicu gangguan hati juga pada janin. Hal ini dikarenakan setelah Ibu mengkonsumsi tape, maka alkohol di kangdungannya akan terbawa di dalam darah dan kemudian menembus plasenta lalu masuk ke tubuh janin. Dari situ di dalam tubuh janin, organ hatinya juga akan ikut dalam proses metabolisme alkohol sehingga ketika bayi lahir, bisa saja bayi mengalami gangguan fngsi hati dan tampak kuning.

Beberapa penelitian telah membuktikan bahwa terdapat hubungan yang signifikan antara konsumsi nanas muda dengan kontraksi uterus. Namun prinsipnya, kandungan bromelin akan menurun seiring dengan bertambahnya tingkat kematangan nanas. Hasil penelitian Apsari et al.(2012) menunjukkan terdapat hubungan yang signifikan antara pemberian ekstrak buah nanas baik yang muda ataupun tua terhadap kontraksi uterus marmut. Namun, pemberian ekstrak buah nanas muda lebih kuat pengaruhnya terhadap peningkatan kontraksi 
uterus dibandingkan ekstrak buah nanas tua. Mungkin, hal inilah yang dapat menjelaskan secara ilmiah mengapa konsumsi buah nanas ditabukan bagi ibu hamil. Tetapi, menurut hasil penelitian Sari, kebiasaan mengonsumsi buah nanas oleh ibu di atas usia kehamilan di atas 36 minggu dapat dilakukan dengan catatan ibu hamil normal tanpa komplikasi dan ibu hamil yang usia kehamilannya sudah matur (Sari, 2010).

\section{Sering Minum Air Kelapa Muda}

Berdasarkan hasil didapatkan bahwa responden memiliki persepsi bahwa ibu hamil yang sering minum air kelapa muda yang setuju sebanyak 25 responden $(61.0 \%)$ dan tidak setuju 16 responden (39.0\%).

Pada masyarakat ini beramsumsi bahwa ibu hamil yang sering minum air kelapa muda sangat bagus untuk kehamilan terutama pada kehamilan usia 4 bulan ke atas, meraka beramsusi bahwa kandungan dalam air kelapa muda bagus untu janin dan untuk memperbanyak air ketuban pada kehamilan ibu.

Selama menjalani masa kehamilan, ibu hamil bisa mengonsumsi air kelapa karena memiliki sejumlah manfaat bagi ibu dan janin. Manfaat tersebut antara lain :

\section{Sumber elektrolit dan antioksidan}

Air kelapa mengandung elektrolit, minum air kelapa bisa mengganti asupan elektrolit yang terbuang saat muntah pada ibu hamil yang mengalami morning sickness. Air kelapa pun mengandung antioksidan yang membantu melenyapkan radikal bebas di tubuh. Untuk hasil yang maksimal, pilihlah air kelapa segar, bukan air kelapa kemasan.

\section{Membantu mengurangi kelelahan}

Kandungan elektrolit dalam air kelapa sangat baik dalam mengganti cairan tubuh yang hilang sehingga ibu hamil terhindar dari dehidrasi. Garam alami pada tubuh dapat digantikan dengan air kelapa karena mengandung garam alami seperti natrium, kalium, dan klorida.

\section{Mencegah infeksi saluran kencing}

Keluhan yang cukup sering dialami ibu hamil adalah infeksi saluran kencing karena adanya perubahan hormon dan perkembangan rahim yang menekan kandung kemih. Air kelapa adalah diuretik alami yang akan membuat ibu hamil lebih mudah untuk mengeluarkan urine dan mencegah terjadinya infeksi saluran kemih. Beberapa wanita terbantu dalam mencegah infeksi saluran kemih dengan mengonsumsi air kelapa.

\section{Melancarkan sirkulasi darah}

Air kelapa untuk ibu hamil juga berguna untuk mengurangi pegal dan nyeri yang diakibatkan tidak optimalnya sistem sirkulasi darah. Jika sistem sirkulasi darah tidak optimal, maka janin berisiko tidak mendapatkan suplai oksigen yang cukup. Kalium dan magnesium yang terdapat dalam air kelapa berperan penting dalam memompa darah ke seluruh tubuh dari jantung. Kalium juga membantu gerakan otot, penghantaran sinyal saraf, dan membantu kerja ginjal dalam penyaringan darah.

Menurut Kemala dan Velayutham (1978), nilai gizi pada air buah kelapa muda, terutama mineral komposisi tertinggi adalah pada umur buah 8 bulan dan mineral $\mathrm{K}$ adalah yang paling tinggi. Oleh karena itu berbagai penelitian menunjukkan bahwa penggunaan air kelapa dapat menyembuhkan beberapa penyakit. Jika ditelusuri susunan komposisi gizi dari jenis-jenis susu formula, maka hampir semua komposisi makro maupun mikronutrien pada daging dan air kelapa muda, terkandung pada susu formula.

\section{Sering Minum Minyak Kelapa}

Berdasarkan hasil didapatkan bahwa responden memiliki persepsi bahwa ibu hamil yang sering minum minyak kelapa yang setuju sebanyak 27 responden (65.9\%) dan tidak setuju 14 responden (34.1\%).

Pada masyarakat ini beramsumsi bahwa ibu hamil yang sering minum minyak kelapa sangat bagus untuk melancarkan kelahiranya karna minum minyak kelapa akan membuat persalinan menjadi lancar karna banyak mengandung minyak.

Buah kelapa memilki cukup banyak manfaat, yaitu sebagai minyak makan atau santan dalam sayur-sayuran. Minyak kelapa murni mengandung asam laurat yang tinggi. Asam laurat adalah asam lemak jenuh yang berantai medium atau biasa disebut Medium Chain Fatty Acid 
(MCFA). Dalam minyak kelapa murni terkandung energi sebanyak $6,8 \mathrm{kal} / \mathrm{gr}$ dan MCFA sebanyak 92\% (Gani, 2005).

Saat ini minyak kelapa banyak digunakan sebagai obat. Minyak kelapa yang dijadikan sebagai obat biasanya disebut minyak kelapa murni (virgin coconut oil/ VCO). Berbagai penyakit yang berasal dari virus dapat ditangkal dengan mengkonsumsi minyak kelapa murni, seperti flu burung, HIV/AIDS, hepatitis, dan jenis virus lainnya. Selain itu, minyak kelapa murni dapat juga mengatasi kegemukan, penyakit kulit, darah tinggi, dan diabetes (Sutarmi dan Rozaline, 2005).

Menurut SNI 7381:2008 minyak kelapa murni adalah minyak yang diperoleh dari daging buah kelapa (Cocos nucifera L.) tua yang segar dan diproses dengan diperas dengan atau tanpa penambahan air, tanpa pemanasan atau pemanasan tidak lebih dari $600 C$ dan aman untuk dikonsumsi. Minyak kelapa murni tidak berwarna (bening), tidak berasa, serta mempunyai aroma yang harum dan khas (Gani, 2005).

Minyak kelapa murni mempunyai sifat tahan terhadap panas, cahaya, oksigen, dan proses degradasi. Sifat itu membuat minyak kelapa murni dapat disimpan dalam jangka waktu yang lama. Dalam pemanfaatannya, minyak kelapa murni dapat dikonsumsi secara langsung ataupun dicampur dengan makanan (Gani, 2005).

VCO mempunyai kandungan asam lemak jenuh yang tinggi. VCO mengandung sekitar $92 \%$ asam lemak jenuh yang terdiri dari asam laurat, miristat, dan palmitat. Kandungan asam lemak jenuh dalam VCO didominasi oleh asam laurat dan asam miristat, sedangkan kandungan asam lemak lainnya rendah. Tingginya asam lemak jenuh yang dikandungnya menyebabkan VCO tahan terhadap proses ketengikan akibat oksidasi (Syah, 2005).

\section{b. Pelaksanaan Budaya/tradisi Syukuran Empat dan Tujuh Bulanan}

Berdasarkan hasil analisis didapatkan mengenai Pelaksanaan Budaya/tradisi
Syukuran Empat dan Tujuh Bulanan yang biasa di lakukan pada masa kehamilan di Desa Cikunir masih mempertahankan upacara empat bulanan dan tujuh bulanan karan acara tersebut merupakan acara yang turun temurun dari nene moyang dan acara yang ritual yang dilakukan pada ibu hamil karna pada ibu hamil usia empat bulan merupakan usia ditiupkannya ruh ke dalam janin.

Acara syukuran empat bulanan ini diadakan secara sederhana dengan mengundang tatangga terdekat dan saudarasaudara dengan kegiatan pengajian yang dipimpin oleh Ustadz yang bertujuan untuk mendo'akan agar bayi dan ibunya sehat, normal, dan selamat selama kehamilan dan pada saat persalinan, selain pengajian proses pengajian ini dibacakan Surah Yaasin, Surah Yusuf dan surah An-nisa pengajian ini bertujuan untuk mendoaakan supaya pesalinanya lancar dan anak yang dilahirkan sehat, sholeh ganteng, sholehah dan cantik, juga dilakukan upacara empat bulanan dan tujuh bulanan ibu hamil juga dimandikan oleh orang tua suami dan keluarga dengan air yang dicampur dengan empat jenis bunga-bungaan yang sudah di Doakan oleh Ustadz dan paraji. Besar kecilnya penyelenggaraan upacara tidak dinilai oleh masyarakat, yang penting upacara ini dilaksanakan. Kepatuhan terhadap tradisi ini juga terjadi pada masyarakat Buton yang masih mempertahankan upacara posipo(upacara untuk ibu hamil anak pertama) (Hindaryatiningsih: 2016).

Syukuran empat bulanan dan tujuh bulanan ini untuk kegiatanya disesuaikan dengan kemampuan ibu hamil dan keluarganya masing-masing, ada beberapa persyaratan yang harus ada yaitu empat macam empat macam beubeutian (umbiumbian) yang di kukus. Pada Usia kehamilan tujuh bulanan diadakan upacara yang serupa. Bedanya pada usia kehamilan tujuh bulanan ini buah-buahan yang disediakan untuk dibuat rujak.

Ritual inisiasi menyampaikan pesan 
simbolis yang menyuarakan nilai dan keyakinan budaya yang sangat dalam (Davis-Floyd: 1992) dan bertujuan untuk melindungi ibu dan janin (dan kadang juga ayah, kerabat dan seluruh keluarga) dari kekuatan jahat (Van Gennep: 2004). Upacara seperti ini juga merupakan bentuk perhatian keluarga dan tetangga serta masyarakat sekitar (Badan Penelitian dan Pengembangan Kesehatan Kementerian Kesehatan RI: 2012) dan juga bertujuan untuk mengenalkan nilai-nilai kebaikan seperti nilai kebersamaan, nilai respect, nilai sosial yang diwujudkan dalam kerelaan membagikan rizki kepada sanak keluarga dan handai taulan yang hadir, sejak anak di dalam kandungan (Hindaryatiningsih : 2016).

Pada masyarakat tradisional, kehamilan dan per-salinan merupakan proses yang normal dan sebagai identitas bagi seorang perempuan (Hillier: 2003). Untuk meyakinkan kesehatan dan keselamatan ibu dan bayinya, masyarakat Desa Karangsari memeriksakan kehamilannya ke bidan dan juga tetap memanfaatkan paraji untuk memeriksa kehamilan, memimpin ritual upacara opat bulanandan nujuh bulanandan juga memberikan saran-saran untuk keselamatan diri dan bayinya.

Hal yang dikemukakan di atas sejalan dengan hasil penelitian Agus et al(2012),
Almutahar (2014) dan Choguya (2014) yang mana dukun bersalin memiliki otoritas dalam kehamilan dan persalinan. Dengan demi-kian, masyarakat Desa Karangsari memanfaatkan akses terhadap pelayanan kesehatan dengan tetap memper-tahankan praktik-praktik tradisional yang didapatkan secara turun-temurun, sesuai dengan hasil kajian Otoo (2015) dan Choudhury et al(2012).

\section{F. DAFTAR PUSTAKA}

Kuswanti, Ina.S. Si. T, M. Kes. 2014. Asuhan kehamilan. Yogyakarta : PT. Pustaka Pelajar

Koentjaraningrat.2005. Pengantar Antropologi II Pokok - Pokok Etnografi, Jakarta: Rineka Cipta,

Lubis, Z. (2003) Posted: 7 November. Status Gizi Ibu Hamil Serta Pengaruhnya Terhadap Bayi Yang Di Lahirkan.

Source:http://pustaka.ictsleman.net/how/k/ kesehatan/12_status_gizi_ibu_hamil.

Mulyana, Deddy. Komunikasi Antar Budaya : Panduan Berkomunikasi Dengan Orangorang Berbeda Budaya. Bandung: Remaja Rosdakarya, 2001.

Mulyana, Deddy.2002.Ilmu Komunikasi : Suatu Pengantar.Bandung : PT Remaja Rosdakarya 


\section{G. DOKUMENTAS}
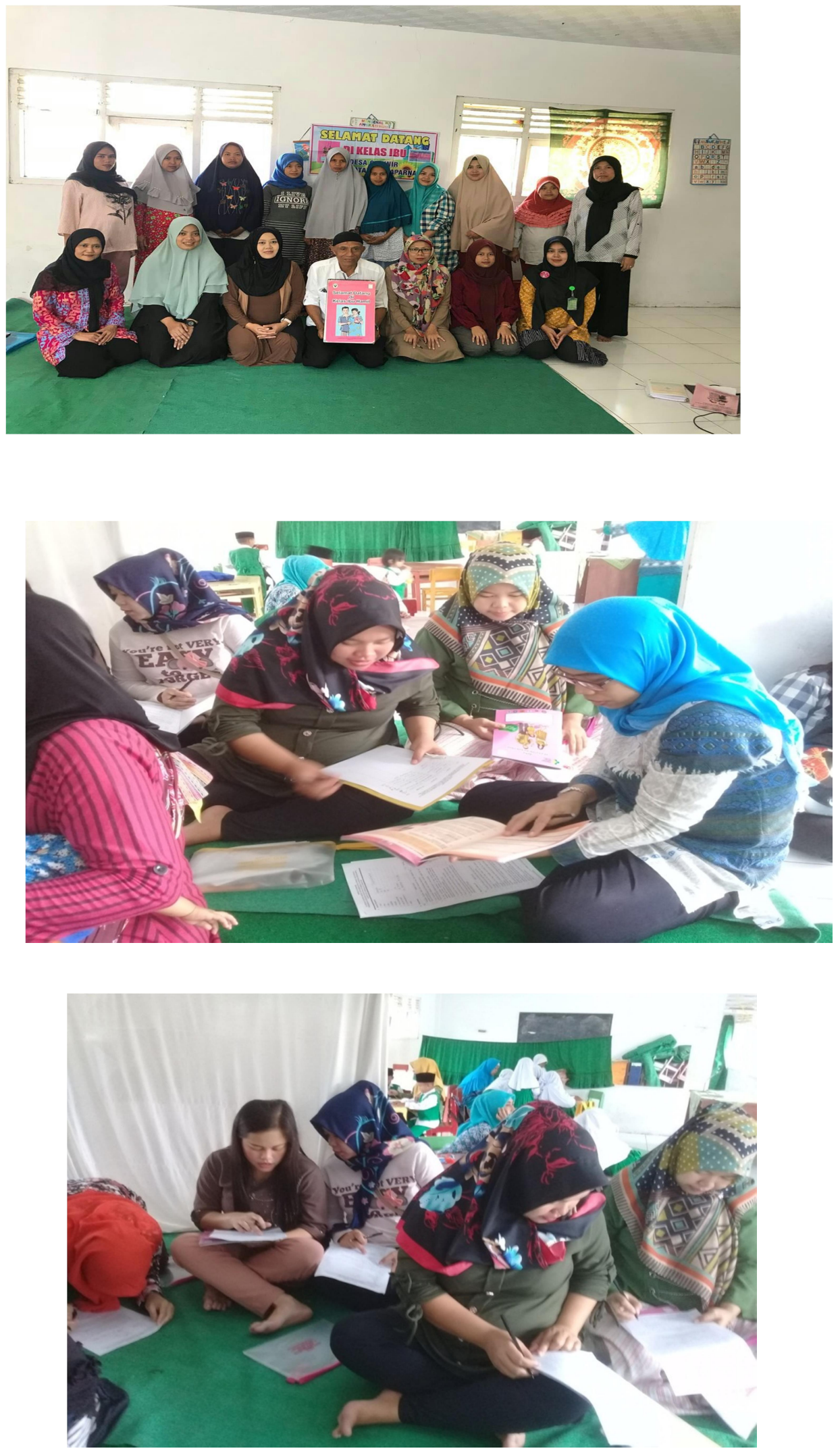